\title{
A review and classification of fossil didemnid ascidian spicules
}

\author{
OSMAN VAROL ${ }^{\prime} \&$ SIMON D. HOUGHTON ${ }^{2}$ \\ 'Varol Research, 12 Tan-y-bryn Road, Rhos-on-Sea, North Wales, LL28 4AE, UK. \\ ${ }^{2}$ FibreCount UK Ltd, Suite 22, Dinnington Business Centre, Outgang Lane, Dinnington, Sheffield S31 7 QY, UK.
}

\begin{abstract}
This study discusses and classifics fossil didemnid ascidian spicules. Three new fossil genera and nine new fossil species are described based on spicule morphology. The genera are Bonetia gen. nov., Rigaudia gen. nov. and Monniotia gen. nov. The species are Bonetia acuta sp. nov., $B$. brevis sp. nov., B. quasitruncata sp. nov., $B$. truncata sp. nov., Rigaudia multiradiata sp. nov., $R$. praecisa sp. nov., Micrascidites pauciradiatus sp. nov., Monniotia acuformis sp. nov., and $M$. fasciculata sp. nov. Recognizing these distinctive fossil didemnid spicules in fine-grained sediments should provide useful palaeoenvironmental information and may stimulate interest in their biostratigraphy. $J$. Micropalaeontol. 15(2): 135-149, October, 1996.
\end{abstract}

\section{INTRODUCTION}

Ascidians, often called sea squirts, are sessile, filter feeding tunicates (subphylum Urochordata) which are important members of marine benthonic communities throughout shelf seas. Living ascidians have attracted a widespread interest from biologists because of their evolutionary position as close relatives of the vertebrate (Plough, 1978).

Although most ascidians are soft-bodied, some species secrete distinctive aragonitic spicules. Didemnid spicules are often found in slides prepared for calcareous nannofossil examination. These stellate or spherical-shaped spicules range in size between 10 and $70 \mu \mathrm{m}$ and, more rarely up to $125 \mu \mathrm{m}$. Although living didemnid ascidians are well known from the continental shelves throughout the world, fossil didemnid spicules are very rarely reported by palaeontologists and, therefore, at present are of little use as palaeoenvironmental or biostratigraphic markers.

This study summarizes the present knowledge of ascidians in relation to didemnid ascidians and fossil ascidian spicules. All type material has been deposited in the Department of Palaeontology, Natural History Museum.

\section{SCOPE OF STUDY}

This study is based on observations by the authors during investigations of nannofossil assemblages from worldwide localities, ranging from Asia, the Middle East, North Africa, Europe and the Gulf of Mexico, over a period of fifteen years. Additionally, the published records of ascidian spicule distribution have been compiled.

\section{BIOLOGY AND ECOLOGY OF ASCIDIANS}

Forms belonging to the subphylum Tunicata have a body (zooid) covered by a complex tunic (from which the name tunicate is derived) containing a substance chemically almost identical with cellulose. The tunicates consist of three classes: the sessile Ascidiacea and the free-floating Thalaliacea and Larvacea. Over 1300 species of Tunicata have been described; the great majority of which belong to the Ascidiacea (Barnes, 1980).
The class Ascidiacea, also known as sea-squirts, are sessile, mostly colonial tunicates and are common marine invertebrates worldwide. The sack-like zooic ranges in size from 1 to $10 \mathrm{~cm}$. Most (c. $95 \%$ ) ascidians form colonies in the shallow water of the continental shelf where they are attached to rocks and shells; or they are occasionally fixed in mud and sand by filaments or stalks. Colonial organization varies within the class, but although the colony itself may grow to a considerable size, usually the individuals forming it are very small (see Plough, 1978, plate VII).

Ascidians are filter feeders and extract plankton from water which passes through the pharynx. The water currents are drawn in through branchial slits by ciliary action. Some deep-sea ascidians obtain their food from the surrounding sediments. Other deep-sea ascidians feed on minute animals (nematodes and epibenthic crustaceans) which are caught with lobes situated around the buccal siphon. Ascidians are hermaphroditic, each individual having male and female gonads. When the eggs are externally fertilized they hatch into free-swimming larvae similar in appearance to tadpoles. However, as the larvae mature, they usually attach themselves to some suitable object and lose their tail.

\section{DIDEMNID ASCIDIANS}

All didemnid ascidians are sessile and colonial, they are common and have a global distribution ranging from the Arctic to the Antarctic (Plough, 1978). Most are found in shallow water $(0-50 \mathrm{~m})$ attached to rocks, shells and other hard surfaces. They are rarely found in deep water, exceptions include Leptoclinides faroensis $(1500 \mathrm{~m})$ and Didemnum albium polare $(1430 \mathrm{~m})$. Didemnid ascidians are depth-sensitive and different species occupy well-defined areas on the sea bottom, conditioned by ocean currents and water temperatures. Ascidians are usually very vulnerable to prolonged freshwater influences. Heavy cyclonic rainfall regularly kills large colonies of ascidians close to the Australian coastline (P. Mather, pers. comm. in Heckel, 1973). Dead ascidian bodies may float on the surface of the sea, where wind, tides and current drift may play a part in their distribution. 


\section{DIDEMNID ASCIDIAN SPICULES}

Ascidians are soft-bodied animals and, with the exception of spicules in didemnid and polycitorid ascidians, they are rarely found as fossils. Monniot (1970) described Cystodytes (Polycitorida) from Pliocene deposits of Brittany, France. Didemnid ascidians secrete fibrous spicules which, according to Matthews (1966), are composed of aragonite with high levels of strontium $(6.5 \%)$. In this study, several specimens recovered in sediments from the Red Sea (DSDP Leg 23, Site 229A) were analysed using energy dispersive X-rays (EDAX) to identify the strontium level. However, only traces of strontium $(<1 \%)$ were observed in the spicules.

The origin of the spicules remains unknown. Loewig \& Koelliker (1846), Hardman (1886), Woodland (1907) and Prenant (1925) suggested that the spicules were developed independently of the zooid, whereas Michelsen (1919), Pérès (1947) and Van Name (1952) indicated that the spicules were products of the zooid and originated in the lateral organs. In living ascidians, the spicules are surrounded by a double-layered membrane (Lafargue \& Kniprath, 1978). Spicule formation is therefore not simply the result of physico-chemical processes.

Spicule characteristics have not been used by biologists for generic level taxonomy of living ascidians. Classification is based instead on a range of soft body elements (see Elredge, 1966). However, at specific level, spicules and their characteristics have been used by many authors as the primary diagnostic feature, in conjunction with characteristics of the zooids.

Presence or absence of spicules, their diameter, ray count, arrangement, distribution and density of rays are usually considered as primary diagnostic criteria, in conjunction with the characteristics of the zooid. However, Berrill (1950) and Elredge (1966) treated these criteria as of secondary importance or disregarded them as given species can be spicular or aspicular depending on environmental controls.

Variations in spicule presence in ascidians could, however, be the result of confusing more than one species whose definitions are only based on the characteristics of the zooid. In a given colony, spicules are usually identical. Van Name (1945) states in a discussion on Didemnum canidum that 'I am far from being able to overcome the fear that I am confusing more than one species, but after the examination of a large amount material from various American localities I am at a loss to find a reliable basis for dividing it by studying museum specimens'.

Spicule distribution and density of cover may very widely not only within a given species, but also occasionally within the same colony. Van Name (1952) suggested that variable distribution and density occurs when colonies undergo a certain amount of regression during unfavourable periods. At such times the spicule remains fixed within the tunic while the zooids degenerate and are added to when new zooids develop.

Waters rich in carbonate, particularly coral reef areas, are especially favourable for the development of didemnid colonies with large spicules with elongated and well-formed conical rays. The attachment of colonies to some rigid object also favours spicule secretion, whereas attachment to a flexible object which allows even slight bending or movement of the test, frequently results in secretion of smaller types of spicules with shorter and less well-formed rays or points. Didemnid spicules secreted in polar and subpolar species are frequently only sparsely distributed in the surface layer of the test and are burr-like with poorly-developed spicule rays (Van Name, 1945; Kott, 1969). Fossil didemnid ascidian spicules of varying shape have been recorded in sediments of Jurassic to Quaternary age (Boekschoten, 1981). Living didemnid ascidians are classified primarily on the characteristics of the zooid; so it is difficult to assign individual spicules to living species. Until now, therefore, Tertiary didemnid spicules which are spherical in shape have been placed in Micrascidites and those which are disc-shaped are assigned to Neanthozoites (produced by Polycitoridae).

If a direct relationship can be established between fossil spicules and living species, the information obtained from living forms may be applied to fossil spicules, assuming they have not changed their habitat with time, and provide useful palaeoenvironmental information.

The occurrence of recent didemnid-spicule-rich sediments seems to be restricted to tropical and subtropical carbonate-rich sediments. Heckel (1973) found high concentrations of didemnid spicules $(>10 \%$ of the nannoplankton fractions) occurred around the main carbonate reef areas of the Great Barrier Reef. Heckel concluded that the spatial distribution of the spicules in the sediments was controlled by selective preservation of the aragonitic spicule rays. Freshwater discharge into the basin severely reduced the preservation potential of the spicules in the sediments.

When studying fossil occurrences of didemnic spicules, special attention must be taken to distinguish in situ occurrences. The durability of didemnid spicules to the processes of erosion, transport and deposition in warm waters is shown by their occurrence in turbidite deposits adjacent to carbonate-rich shelf environments (Beall \& Fischer, 1963: Wei, 1993). Didemnid spicules also survive digestion and have been reported in fish guts (Rae, 1967) confirming fish predation and indicating another method of dispersal of the spicules from their sessile habitat into soft sediments.

Spicules are composed of aragonite and thus are highly susceptible to dissolution. Stieglitz (1972) recorded strongly etched didemnid spicules from Recent sediments from the Bimini Lagoon, Bahamas. Aragonite dissolution in freshwater phreatic environments in tropical areas has also been well documented (Land, 1970). The recovery of spicules in sediments therefore suggests high sedimentation rates and/or rapid sealing of sediments soon after deposition (Houghton \& Jenkins, 1988).

The susceptibility of ascidian spicules to dissolution and diagenesis may restrict their value as biostratigraphic indicators. However, although ascidians are mainly benthic, they also have a free-swimming (tadpole) larval phase. This initial pelagic life cycle, coupled with a reported cosmopolitan distribution of many species (Knott, 1969; 
Plough, 1970) may yet indicate that ascidian spicules have potential interbasin correlation in well-preserved sections.

Hypersaline lagoonal and shallow water carbonate platform sequences should provide fruitful starting materials. Ascidian spicules are reported to be particularly common in faecal pellets and other carbonate mud aggregates of the Great Bahamas Bank (Purdy, 1963). Significantly, as diagenesis proceeded, only ascidian spicules were found to remain as the non-recrystallized constituents within the pellets. Didemnid spicules also occur in carbonate muds deposited in lagoons and carbonate shoals from Belize (Matthews, 1966) and in the Bimini Lagoon, Bahamas (Stiegletz, 1972).

The stratigraphical and geographical distribution of ascidian spicules for the Mesozoic and Tertiary-Quaternary are given in Tables 1 to 2 . The biostratigraphical potential of didemnid spicules has still to be explored, and full stratigraphic ranges of the species are yet to be established. However, a few are already known to be moderately good zonal markers. For example, Kokia, a possible ascidian spicule, has so far been documented from Valanginian to Berriasian sediments of the North Sea area. However, van Niel (1994) suggests that Kokia specimens show a construction similar to calcareous pentalith genera in the Braarudosphaeracae; but because of their high number of rays, Kokia should still be considered 'incertae sedis'. Didemnum minutum seems to be restricted to the Middle and Upper Jurassic and has a wide geographical distribution. High frequency variations of spicule abundance could also be used for local biostratigraphic correlation (cf. Heckel, 1973).

Wei (1993) studied tunicate spicule abundances in sediments from the Great Barrier Reef and Queensland Plateau (ODP Leg 133 sites) and concluded that tunicate spicules do not appear to be promising biostratigraphic markers for the Pliocene-Pleistocene. However, listed below are the tentative ranges of the genera described here: (a) Monniotia recorded range Pleistocene

(b) Rigaudia recorded range Pliocene-Pleistocene

\begin{tabular}{|c|c|c|}
\hline AGE & AUTHORS & AREA \\
\hline \multicolumn{3}{|c|}{ Micrascidites vulgaris } \\
\hline Quaternary - Pliocene & $\begin{array}{l}\text { Durand, } 1948 \text { \& } 1955 \\
\text { Chauvel, } 1952 \\
\text { Durand \& Pelhate, } 1961 \\
\text { Bonet \& Beneviste-Velasquez, } 1971 \\
\text { Cita, } 1973 \\
\text { Houghton \& Jenkins, } 1988 \\
\text { Wei, } 1993\end{array}$ & $\begin{array}{l}\text { France } \\
\text { France } \\
\text { France } \\
\text { Mexico } \\
\text { Mediterranean } \\
\text { Celtic Sea } \\
\text { Great Barrier Reef } \\
\end{array}$ \\
\hline Miocene & $\begin{array}{l}\text { Deflandre \& Deflandre-Rigaud, } 1956 \\
\text { Deflandre-Rigaud, } 1968 \\
\text { Monniot \& Buge, } 1971 \\
\text { Heckel, } 1973 \\
\text { Varol, } 1985\end{array}$ & $\begin{array}{l}\text { Australia } \\
\text { Australia } \\
\text { France } \\
\text { Australia } \\
\text { Turkey }\end{array}$ \\
\hline Eocene & $\begin{array}{l}\text { Deflandre-Rigaud, 1949; 1956 \& } 1968 \\
\text { Durand, } 1952 \\
\text { Deflandre \& Deflandre-Rigaud, } 1956 \\
\text { Bouche, } 1962 \\
\text { Lezaud, } 1966\end{array}$ & $\begin{array}{l}\text { France } \\
\text { France } \\
\text { France } \\
\text { France } \\
\text { France }\end{array}$ \\
\hline \multicolumn{3}{|c|}{ Rigaudia } \\
\hline Pleistocene & $\begin{array}{l}\text { Edwards, } 1973 \\
\text { (described as Micrascidites vulgaris) } \\
\text { Wei, } 1993 \\
\text { (described as Tunicate spicules) }\end{array}$ & $\begin{array}{l}\text { Coral Sea } \\
\text { Great Barrier Reef }\end{array}$ \\
\hline \multicolumn{3}{|c|}{ Bonetia } \\
\hline Pleistocene-Pliocene & $\begin{array}{l}\text { Wei, } 1993 \\
\text { (described as Tunicate spicules) }\end{array}$ & Great Barrier Reef \\
\hline \multicolumn{3}{|c|}{ Monniotia } \\
\hline Pleistocene - Pliocene & $\begin{array}{l}\text { Wei, } 1993 \\
\text { (described as Tunicate spicules) }\end{array}$ & Great Barrier Reef \\
\hline
\end{tabular}

Table 1. Stratigraphical and geographical distribution of Tertiary and Quaternary ascidian spicules. 


\begin{tabular}{|c|c|c|c|}
\hline SPECIES & AGE & AREA & AUTHORS \\
\hline Asciditites dubius & Sinemurian - Tithonian & Mexico & Bonet \& Benveniste-Velasquez, 197 \\
\hline Micrascidites irregularis & Toarcian & Mexico & Buge \& Monniot, 1972 \\
\hline Cystodites sp. & Toarcian & France & Buge \& Monniot, 1972 \\
\hline Didemnum minutum & Callovian & $\begin{array}{l}\text { Mexico } \\
\text { Britain }\end{array}$ & $\begin{array}{l}\text { Bonet \& Benveniste-Velasquez, } 197 \\
\text { Varol \& Girgis, } 1994\end{array}$ \\
\hline Didemnoides rosetta & Kimmeridgian - Hauterivian & Mexico & Bonet \& Benveniste-Velasquez. 197 \\
\hline Didemnum shetlandensis & Valanginian & North Sea & $\begin{array}{l}\text { Perch-Nielsen, } 1988 \\
\text { Varol \& Girgis. } 1994\end{array}$ \\
\hline Didemnum cascianum & $\begin{array}{l}\text { Carnian } \\
\text { Rhaetian } \\
\text { Carnian - Rhaetian }\end{array}$ & $\begin{array}{l}\text { Germany } \\
\text { Irian Jaya } \\
\text { Indian Ocean } \\
\end{array}$ & $\begin{array}{l}\text { Jafar, } 1983 \\
\text { Varol \& Girgis, } 1994 \\
\text { Bralower et al., } 1991\end{array}$ \\
\hline Didemmum pseudotrifidum & Rhaetian & $\begin{array}{l}\text { Germany } \\
\text { Irian Jaya }\end{array}$ & $\begin{array}{l}\text { Jafar, } 1983 \\
\text { Varol \& Girgis, } 1994\end{array}$ \\
\hline Rucinolithus? magnus & $\begin{array}{l}\text { Campanian } \\
\text { Campanian } \\
\text { Campanian } \\
\text { Campanian-Eocene }\end{array}$ & $\begin{array}{l}\text { Atlantic } \\
\text { NW Pacific } \\
\text { Turkey } \\
\text { Pacific }\end{array}$ & $\begin{array}{l}\text { Cita \& Garner, } 1971 \\
\text { Bukry, } 1975 \\
\text { Varol, } 1983 \\
\text { Bergen, } 1985\end{array}$ \\
\hline \multicolumn{4}{|c|}{ Tentative ascidian spicules } \\
\hline Kokia borealis & $\begin{array}{l}\text { Berriasian } \\
\text { Valanginian } \\
\text { Valanginian-upper Ryazanian } \\
\text { upper Ryazanian }\end{array}$ & North Sea & $\begin{array}{l}\text { Perch-Nielsen, } 1988 \\
\text { Kok, } 1985 \\
\text { Varol \& Girgis, } 1994 \\
\text { van Niel, } 1994\end{array}$ \\
\hline Kokia curvata & Valanginian & North Sea & Perch-Nielsen, 1988 \\
\hline Kokia sp.A & upper Ryazanian & North Sca & van Niel, 1994 \\
\hline Kokia sp. 1 & Hauterivian & North Sea & Perch-Nielsen, 1988 \\
\hline
\end{tabular}

Table 2. Stratigraphic and geographical distribution of Mesozoic ascidian spicules and other possibly related spicules.

(c) Bonnetia recorded range Middle Miocene-Pleistocene

(d) Micrascidites recorded range Lower Eocene-Pleistocene.

\section{MORPHOLOGY OF SPICULES}

The arrangement and shape of the rays in spicules can be utilized as diagnostic features for the identification of genera. The ratio of the length of the free part of the ray to that of the joined part, together with the number and density of rays, are used for the determination of the species. The stellate spicules are assigned to the genus Micrascidites and the spherical spicules assigned to the new genera Bonetia, Rigaudia and Monniotia.

Spicule rays are defined as the parts in which a spicule is naturally separated or divided. Each ray therefore has two parts: the joined part (where each ray joins to the next) and the free part. The joined inner parts of the rays are always conical with their apices towards the centre, whereas the free parts of the rays may be conical, truncated conical or cylindrical.

In this study, four major types of ray were identified and this led to the recognition of three new genera (Fig. 1).

1. Micrascidites-type rays are biconical or rhomboid in axial section, without an inflection between the free and joined parts of the rays.

2. Bonetia-type rays are biconical, but with a distinct inflection between the joined and free parts. The rays are widest in diameter along the jointed part of the rays. The free part is always narrower and is conical or truncated conical.

3. Rigaudia-type rays resemble a sharpened pencil. Their free lengths are cylindrical, with parallel sides to the ray and a truncated peripheral end.

4. Monniotia-type rays are unequal in length, composite and are constructed of needle-like elements forming bundlelike structures with or without a free part.

Two major types of spicule construction have been recognized in this study: (a) stellate spicules; (b) spherical spicules.

Stellate spicules are composite spicules constructed of several layers of petaloid units which may be flat or concavo-convex. In these petaloid layers each spicule ray radiates from the centre of the unit. Adjacent petaloid cycles are then joined in a saddle-like manner to form a complete spicule (Fig. 2). The number of rays is reduced towards the outermost cycle. Stellate spicules are found in Micrascidites.

Spherical spicules are constructed from rays which radiate from the centre of the spicule and are found in Bonetia, Rigaudia and Monniotia. All the rays in the spicules are approximately the same length.

An advantage of using spicule morphology as a system of classification is that individual species may be identified even if only isolated rays are preserved rather than complete spicules. 
Fossil didemnid ascidian spicules

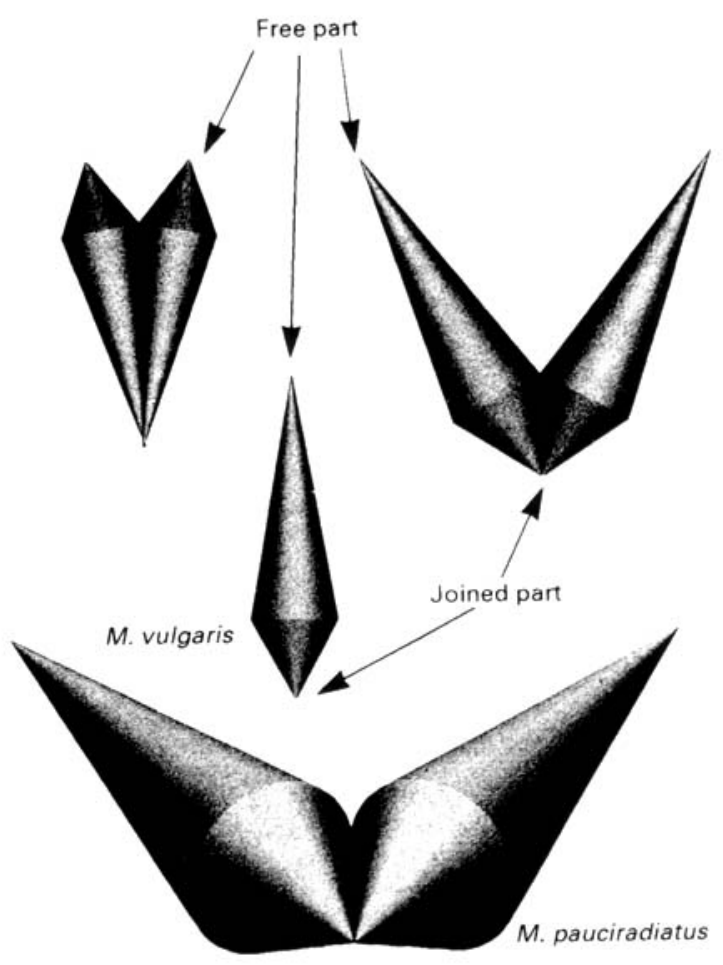

(a)
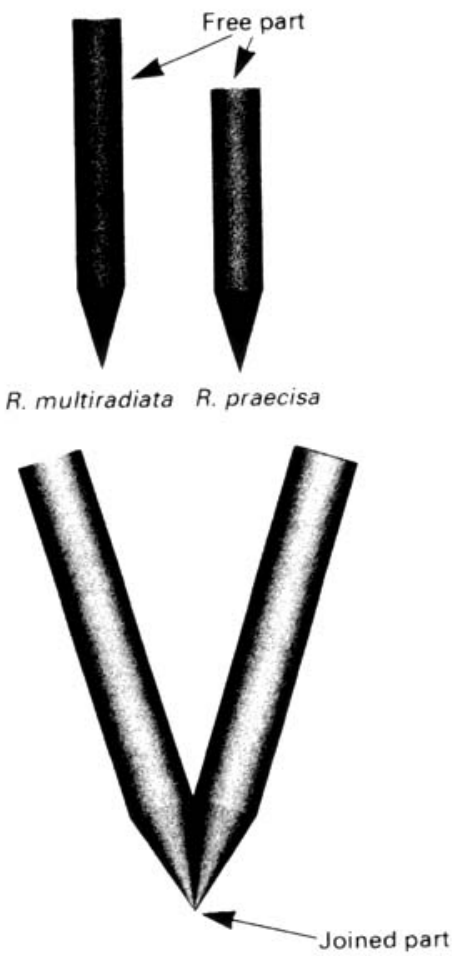

(c)
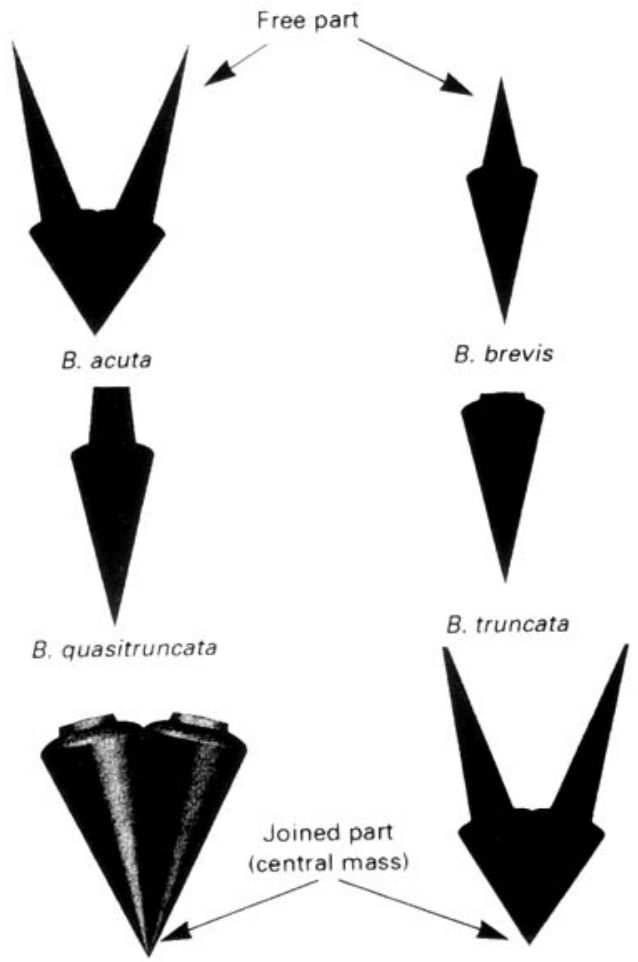

(b)
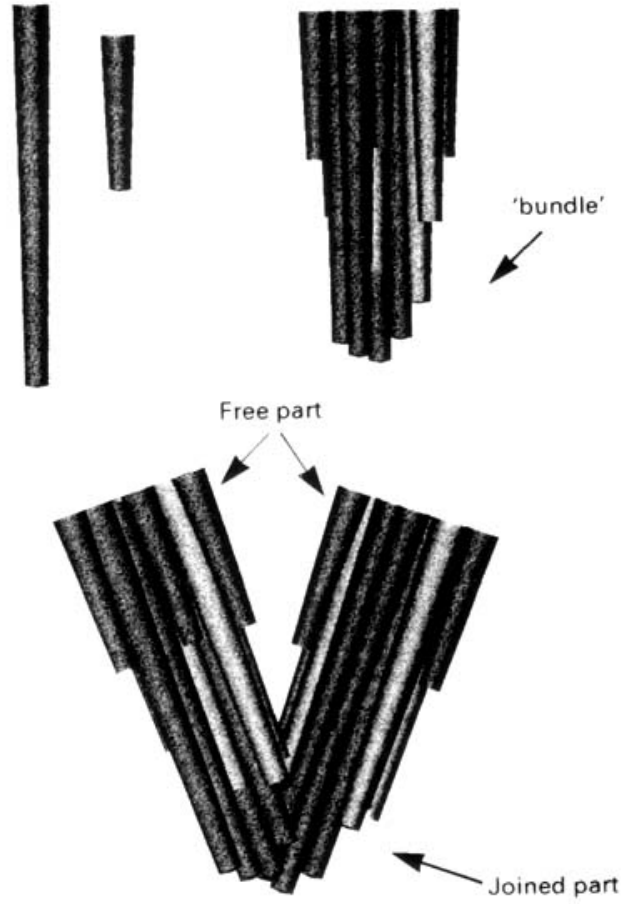

(d)

Fig. 1. Micrascidites-type, Bonetia-type, Rigaudia-type and Monniotia-type spicule rays.

\section{CONCLUSIONS}

Didemnid ascidian spicules should have been more widely reported in the fossil record, but have probably been overlooked by many palaeontologists because of their small size, their tendency to break up in to individual spicule rays, and possible confusion as to their organic origin. Future 

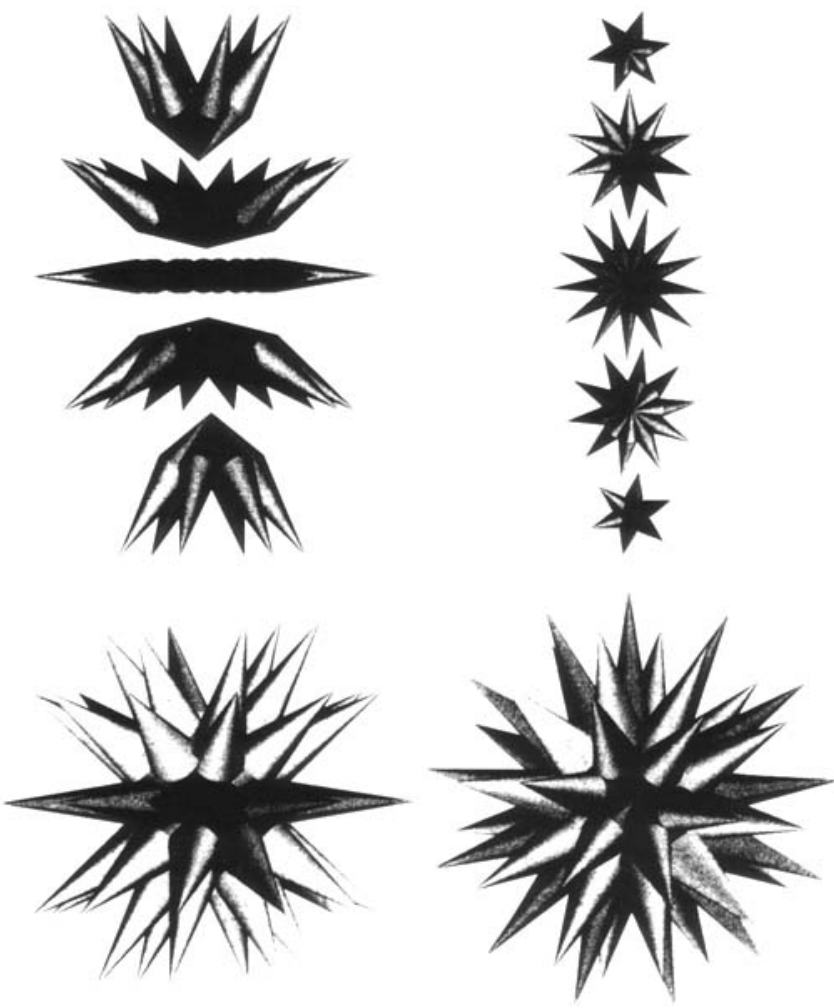

side view

plan view

Fig. 2. Structural units of Micrascidites.

studies on didemnic spicules should concentrate on mapping their areal distribution in sediments and also provide detailed morphological descriptions. Such studies should be particularly useful in palaeoenvironmental analysis of fine-grained sediments and also should determine their value as biostratigraphical markers.

The aragonitic spicules of didemnid ascidians are more susceptible to solution than the calcitic remains of coccoliths and foraminifera. The didemnid spicules, like aragonitic pteropods, are therefore likely to be better preserved in basins having high bottom water temperatures, sluggish circulation, and rapid sedimentation rates such as the Mediterranean Sea, Red Sea and the Persian Gulf.

\section{SYSTEMATIC DESCRIPTIONS}

Subphyllum Tonicata Lamarck, 1816

Class Ascidiacea Blainville, 1825

Order Enterogona Perrier, 1898

Suborder Aplousobranchia Lahille, 1886

Family Didemnidae Milne Edwards, 1891

Genus Bonetia Varol \& Houghton, gen. nov.

Type species. Bonetia brevis sp. nov.

Derivation of name. In honour of Dr. F. Bonet, Mexico. Diagnosis. Spherical spicules with conical or truncated conical rays which have a greater diameter in the joined part of the ray than the free part (Bonetia-type rays). These rays radiate from the centre of the spicule. Different species of this genus are distinguished by the number of rays, shape of the free part, and ratio of the length of the free part to that of the joined part of the rays.

Remarks. Bonetia differs from Micrascidites by having rays which are greater in diameter along the joined part of the ray, whilst the latter has rhomboidal rays. Bonetia is a spherical spicule, whereas Micrascidites is a stellate spicule. Other spherical spicules, Rigaudia and Monniotia, are distinguished from Bonetia by having rays with a cylindrical free length and needle-like bundle rays respectively.

Bonetia acuta sp. nov.

(Pl. 1, fig. 9; Pl. 2, figs 6, 9; Pl.3, fig. 4; Pl.4, fig. 14)

1993 Tunicate spicules Wei: pl. 1, figs $1-2$.

Derivation of name. From latin acutus ( $=$ sharpened).

Diagnosis. Species of Bonetia with spicules containing 20-30 rays in which the free part is conical with a length greater than that of the joined part.

Holotype. Pl. 2, fig. 9. (NF514/Neg. 9).

Type level and locality. Late Pleistocene (Zone NN21), Red Sea (DSDP Leg 23, Site 229A, Core 2, Section 5, $40-45 \mathrm{~cm}$ ).

Dimensions of holotype. Diameter of spicule $=29.0 \mu \mathrm{m}$ length of free part of rays $=8.5 \mu \mathrm{m}$.

Remarks. $B$. acuta is distinguished from $B$. brevis by having fewer rays (20-30) and by the length of the free part of the rays always being greater than that of the jointed part. $B$. truncata and $B$. quasitruncata have rays with truncated free parts.

Occurrence. Pliocene to Pleistocene of the Red Sea, Middle Miocene of southern Turkey, and middle Miocene to Pleistocene of Indonesia, India, West Africa and Egypt.

Bonetia brevis sp. nov.

(Pl. 2, fig. 8; Pl. 3, fig. 5; Pl. 4, figs 11-12)

Derivation of name. From Latin brevis (=short).

Diagnosis. Species of Bonetia with 40-60 rays per spicule which have the conical free parts shorter than the joined part of each ray.

Holotype. P1. 2, fig. 8 (NF514/Neg. 8).

Type level and locality. Late Pleistocene (Zone NN21), Red Sea (DSDP Leg 23, Site 229A Core 2, Section 5, $40-45 \mathrm{~cm}$ ).

Dimensions of holotype. Diameter of spicule $21.0 \mu \mathrm{m}$; length of free part of rays $3.0 \mu \mathrm{m}$.

Occurrence. Late Pleistocene sediments of the Red Sea and Middle Miocene sediments of southern Turkey.

Bonetia quasitruncata sp. nov.

(Pl. 2, fig. 5; Pl. 4, figs 9-10)

Derivation of name. From latin quasi (= almost).

\section{Explanation of Plate 1}

Note that all SEM micrographs are from the Late Pleistocene of the Red Sca (DSDP Leg 23, Site 229A), unless otherwise stated.

Figs 1-4. Micrascidities vulgaris: fig. 1, $\times 4200$; Fig. 2, $\times 4900$; Fig. 3, $\times 6300$; Fig. 4, $\times 9800$. Figs 5-8. Rigaudia multiradiata sp. nov. Holotype (Fig. 5): Fig. 5, $\times 4900$; Fig. 6, $\times 14700$; Fig. 7, $\times 5600$ : Fig. 8, $\times 12600$. Fig. 9. Bonetia acuta sp. nov. $\times 7700$. 
Fossil didemnid ascidian spicules
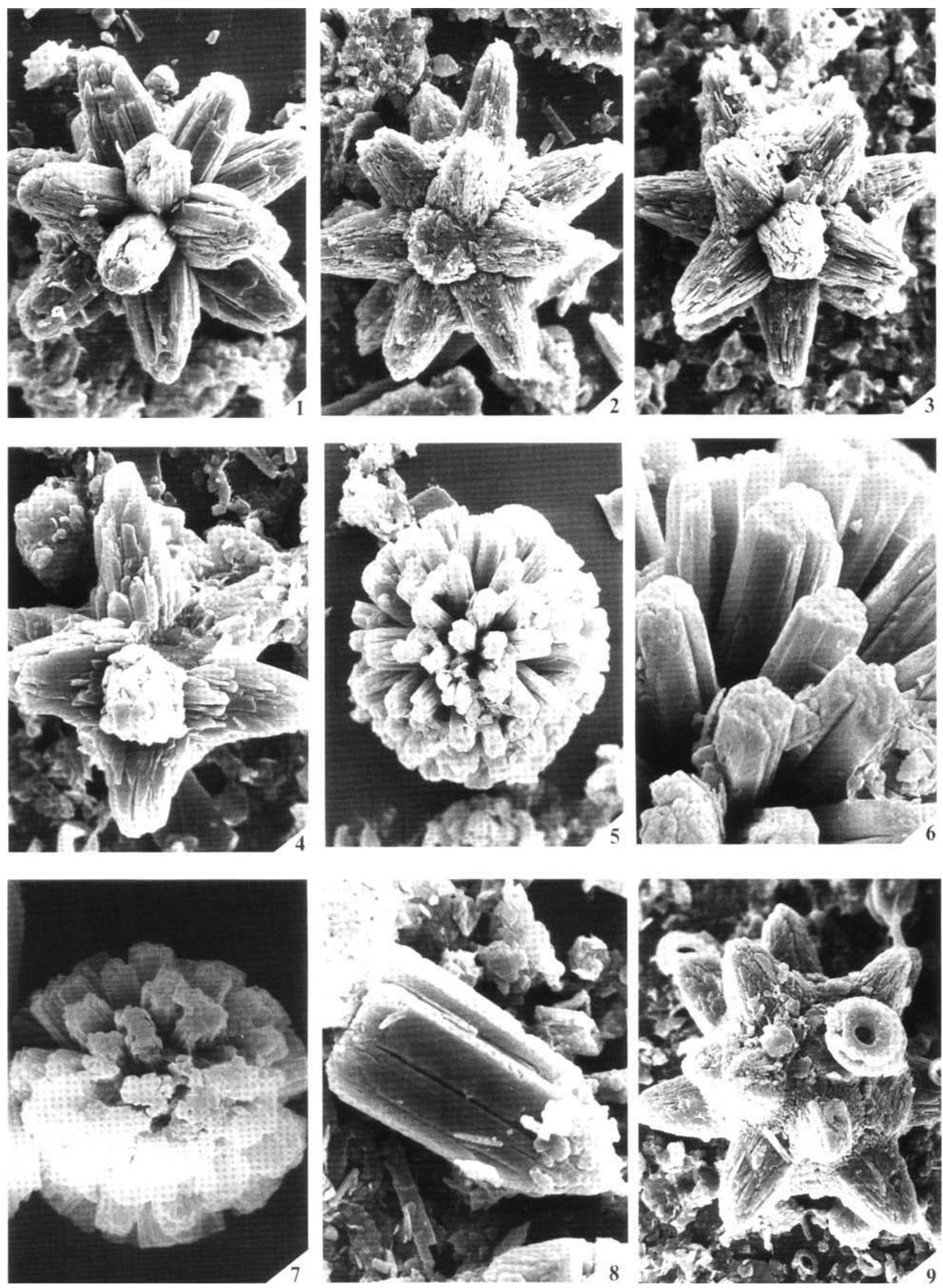

Plate 1 

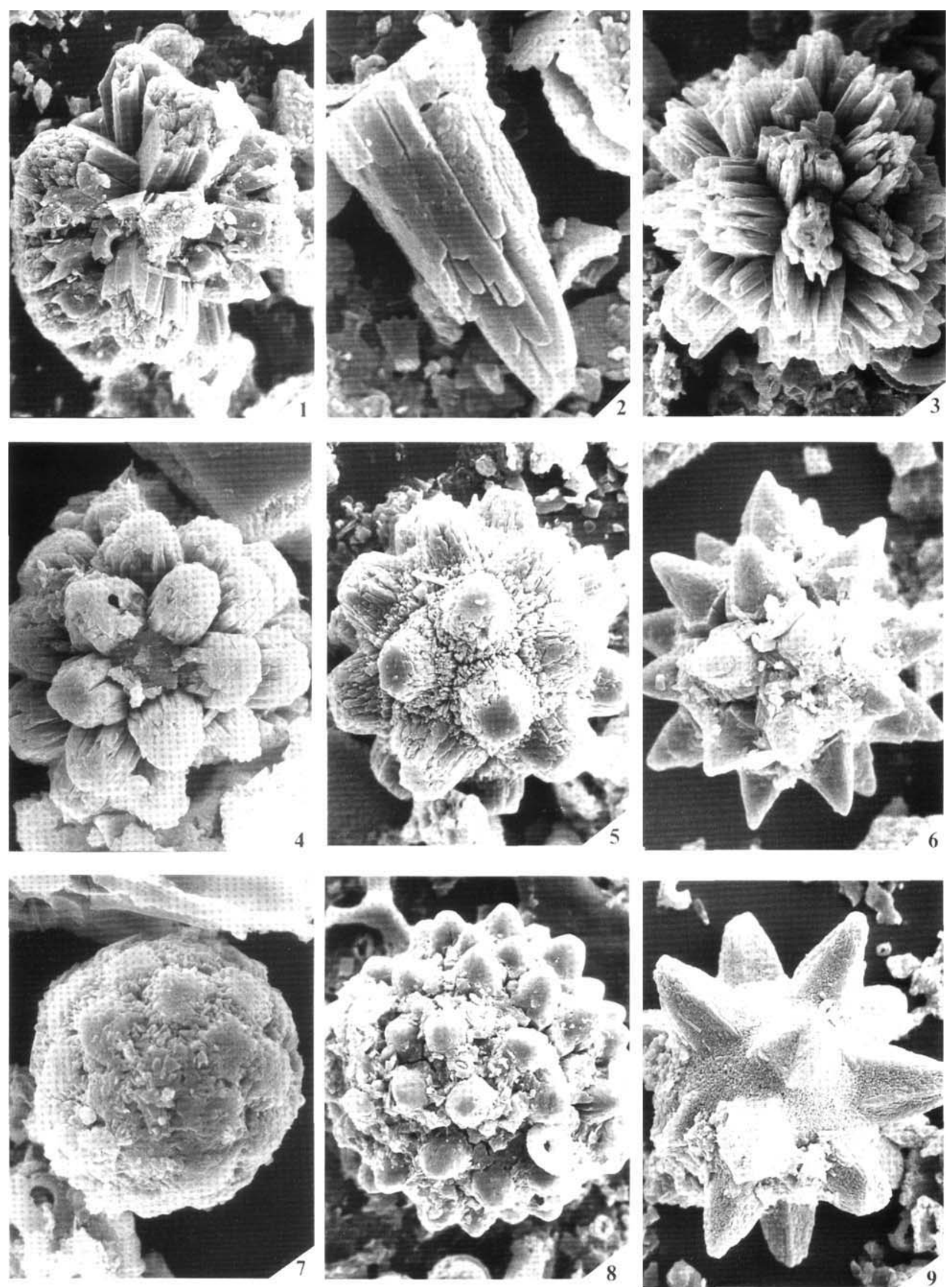

Plate 2

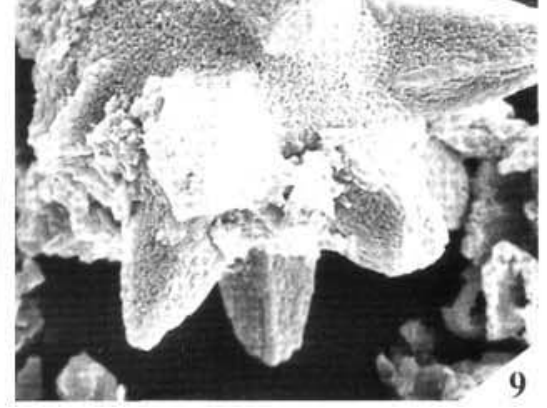


Diagnosis. Species of Bonetia with 20-30 rays per spicule in which the free part is a truncated cone in shape.

Holotype. Pl. 2, figs 5 (NF514/Neg. 6)

Type level and locality. Late Pleistocene (Zone NN21), Red Sea (DSDP Leg 23, Site 229A, Core 2, Section 5, $40-45 \mathrm{~cm}$ ).

Dimensions of holotype. Diameter of spicule $=21.0 \mu \mathrm{m}$; length of the free part of the rays $2.5 \mu \mathrm{m}$.

Remarks. $B$. quasitruncata differs from $B$. truncata by having rays with distinct truncated cone-shaped free parts, whereas the latter has a higher number of rays that are practically without a free part.

Occurrence. Pleistocene sediments of the Red Sea and the Gulf of Aden.

\section{Bonetia truncata sp. nov.}

(Pl. 2, fig. 7)

Derivation of name. Latin truncatus (= cut off), referring to the truncated free part of the rays.

Diagnosis. Species of Bonetia having spicules containing $35-50$ rays without free parts.

Holotype. Pl. 2, fig. 7 (NF414/Neg. 5)

Type level and locality. Late Pleistocene (Zone NN21), Red Sea (DSDP Leg 23, Site 229A, Core 2, Section 5, $40-45 \mathrm{~cm}$ ).

Dimensions of holotype. Diameter of spicule $=12.0 \mu \mathrm{m}$, maximum diameter of rays $=2.0 \mu \mathrm{m}$ ).

Remarks. B. truncata is distinguished from other species of Bonetia by having spicules with rays practically without a free part.

Occurrence. Pleistocene sediments of the Red Sea and Gulf of Aden.

Genus Rigaudia Varol \& Houghton gen. nov.

Type species. Rigaudia multiradiata sp. nov.

Derivation of name. In honour of $\mathrm{Dr} M$. DeflandreRigaud, Paris.

Diagnosis. Spherical spicule having numerous rays in which the free part is cylindrical with a truncated distal end. These rays radiate from the centre of the sphere. The ravs are partly joined and the inter-ray areas are usually narrow. Species of this genus are distinguished the length, diameter, number and density of rays.

\section{Rigaudia multiradiata sp. nov.}

(Pl. 1, figs 5-8; Pl. 5, fig 1-4)

1973 Micrascidities vulgaris 1956 Edwards: 663, PI. 2, figs 1, 3-4.

1993 Tunicate spicules Wei: Pl. 2, figs 12, 14-15.

Derivation of name. From latin multus (= many); radius (= ray), referrring to the high number of rays.

Diagnosis. Species of Rigaudia with 70-90 thin cylindrical pencil-like rays which leave narrow inter-ray spaces.

Holotype. Pl. 1, fig. 5 (NF514/Negs. 1).
Type level and locality. Late Pleistocene (Zone NN21), Red Sea (DSDP Leg 23, Site 229A, Core 2, Section 5, depth $40-45 \mathrm{~cm}$ ).

Dimensions of holotype. Diameter of spicule $=19.5 \mu \mathrm{m}$; maximum diameter of rays $=1.7 \mu \mathrm{m}$.

Remarks. $R$. multiradiata differs from $R$. praecisa by having a greater number (70-90) of thinner and longer rays, than the latter which has $30-45$ thicker and shorter rays.

Occurrence. Pleistocene sediments of the Red Sea and the Gulf of Aden. Also recorded by Edwards (1973) in Pleistoce sediments from Leg 21 of DSDP in the southwest Pacific.

Rigaudia praecisa sp. nov.

(Pl. 2, fig. 4: Pl. 4, figs 15-17)

Derivation of name. From latin praecisa, (=cut off), referring to the truncated peripheral ends of the rays.

Diagnosis. species of Rigaudia having 30-45 moderately thick and short pencil-like rays radiating from the centre of the sphere.

Holotype. Pl. 2, fig. 4 (NF514/Neg. 4).

Type level and locality. Late Pleistocene (Zone NN21), Red Sea (DSDP Leg 23, Site 22A, Core 2, Section 5, $40-45 \mathrm{~cm}$ ).

Dimensions of holotype. Diameter of spicule $=14.5 \mu \mathrm{m}$; maximum diameter of rays $=2.7 \mu \mathrm{m}$.

Occurrence. Pleistocene of the Red Sea, Gulf of Aden, Indonesia and Egypt.

Genus Micrascidites Deflandre \& Deflandre-Rigaud, 1956 Type species. Micrascidites vulgaris Deflendre \& Deflandre-Rigaud, 1956.

Remarks. Stellate spicules with rhomboidal or biconical rays.

\section{Micrascidites pauciradiatus $\mathrm{sp}$. nov}

(Pl. 3, fig. 2; Pl. 5, figs 11-12)

1993 Tunicate spicules Wei: pl. 2, figs 1-3, 8 .

Derivation of name. From Latin paucit $(=\mathrm{few}$ in number), referring to the low number of rays.

Diagnosis. species of Micrascidites having three to five large rhomboidal rays in which the length of the free part is at least five times, and maximum diameter is at least two times, greater than the length of the jointed part.

Holotype. Pl. 5, fig. 11 (NF514/Neg. 11).

Type level and locality. Late Pleistocene (Zone NN21), Red Sea (DSDP Leg 23, Site 229A, Core 2, Section 5, depth $40-45 \mathrm{~cm}$ ).

Dimensions of holotype. Diameter of spicule $=21.5 \mu \mathrm{m}$; maximum length of rays $=11.0 \mu \mathrm{m}$, maximum width $5.0 \mu \mathrm{m}$, maximum length of joined part $=2.0 \mu \mathrm{m}$.

Figs 1-3. Monniotia fasciculata sp. nov. Holotype (Fig. 3): Fig. 1, $\times 4200$; Fig. 2, $\times 16100$ : Fig. 3, $\times 7700$. Fig. 4. Rigaudia praeisa sp. nov. Holotype; $\times 7700$. Fig. 5. Bonetia quasitruncata sp. nov. Holotype; $\times 4900$. Figs 6, 9. Bonetia acuta sp. nov. Holotype (Fig. 9): Fig. 6, $\times 4900$ Fig. 9, $\times 4200$. Fig. 7. Bonetia truncata sp. nov. Holotype; $\times 7700$. Fig. 8. Bonetia brevis sp. nov. Holotype; $\times 4900$. 

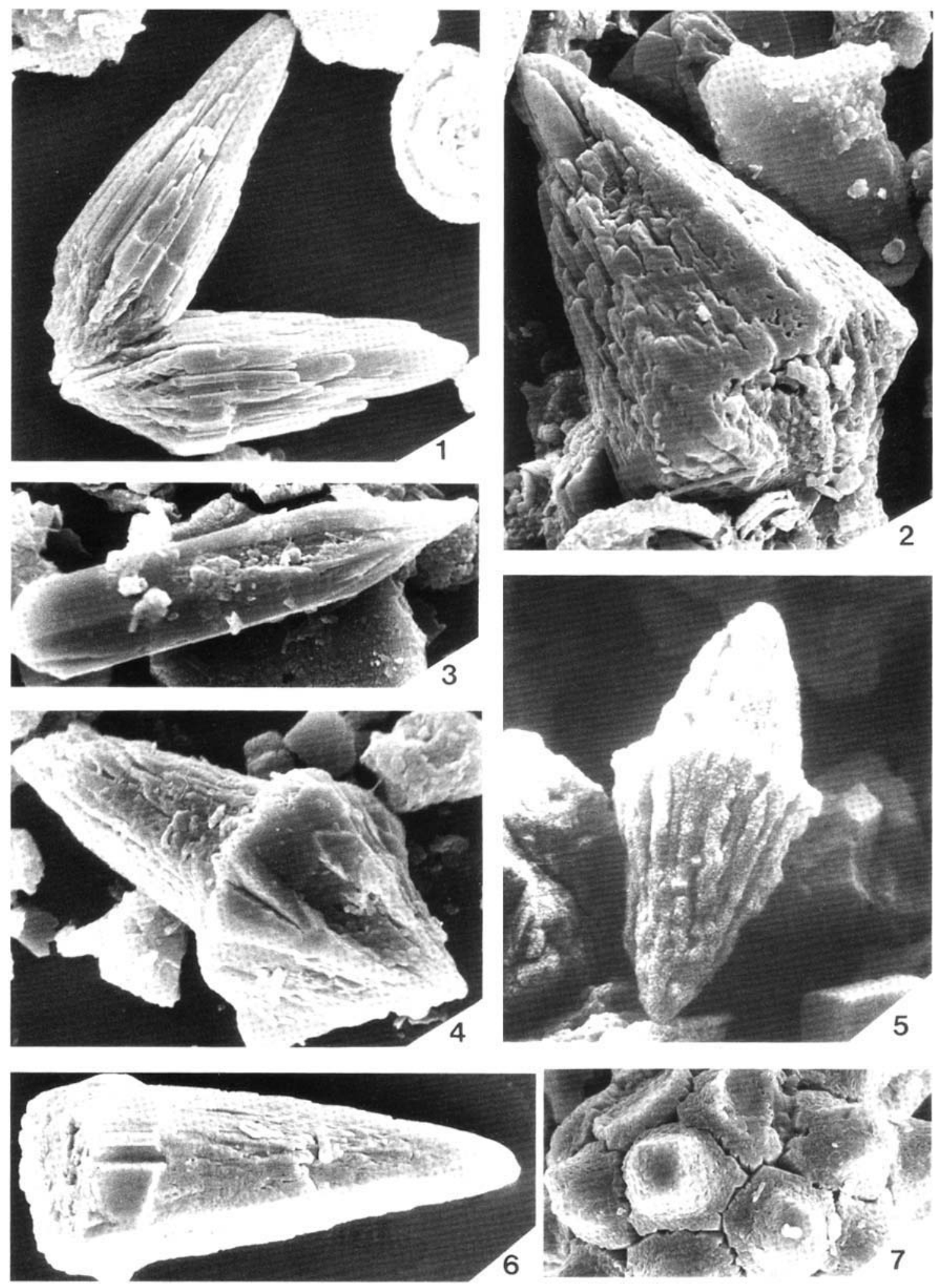

Plate 3 
Remarks. $M$. pauciradiatus is distinguished from $M$. vulgaris by having fewer rays (3-5) and a greater ratio of length of free part to that of the jointed part of the ray. This ratio is more than $4: 1$ in $M$. pauciradiatus whereas it is less than $3: 1$ in $M$. vulgaris.

Occurrence. Middle Miocene sediments of southern Turkey and Indonesia, and Pliocene to Pleistocene sediments of the Red Sea, Gulf of Aden, Indonesia and Egypt.

Micrascidites vulgaris Deflandre \& Deflandre-Rigaund, 1956 (Pl. 1, figs 1-4; Pl. 3, fig. 1; Pl. 5, figs 5-9)

Remarks. The number of rays varies between 8 and 30 . The free parts of the rays are conical with bluntly pointed peripheral ends. Further subdivision of this species may be possible using number of rays and ratio of the length of the free part to that of the joined part.

Occurrence. This species has been reported from Eocene to quaternary sediments (Table 2). In the present study it is also recorded from deposits of similar age worldwide.

Genus Monniotia Varol \& Houghton gen. nov.

Type species. Monniotia fasciculata sp. nov.

Derivation of name. In honour of $\mathrm{Dr} F$. Monniot, Paris.

Diagnosis. Spherical spicules having rays which are needle-like and unequal in length, only some of which extend to the centre of the sphere. The rays may or may not have a free part.

Remarks. Monniotia differs from other spherical spicules such as Bonetia and Rigaudia by having rays constructed of needle-like elements (Monniotia-type), which taper towards the centre of the spicule. The composite Monniotia spicule rays all radiate from the centre of the sphere. In contrast, the genera Bonetia and Rigaudia have conical or truncated conical rays and truncated cylindrical rays which all radiate from the centre of the sphere respectively.

Monniotia fasciculata sp. nov.

(Pl. 2, figs 1-3; Pl. 4, figs 1-4)

1993 Tunicate spicules Wei: Pl. 1, fig. 1.

Derivation of name. From Latin fasciculatus, ( = joined in small bundles), referring to the construction of rays from needle-like elements.

Diagnosis. Species of Monniotia having spicules with rays which are arranged in bundles and which have no free parts.

Holotype. Pl. 2, fig. 3 (NF514/Neg. 3).

Type level and locality. Late Pleistocene (Zone NN21), Red Sea (DSDP Leg 23, Site 229A, Core 2, Section 5, depth $40-45 \mathrm{~cm}$ ).

Description. Spherical spicules containing $20-40$ bundlelike spicule rays. Each spicule ray is constructed of 10-20 needle-like elements which are unequal in length. Each ray consists of a fee part and joined part. Only a few of the spicule rays extend to the centre of the spherical spicule.

Dimensions of holotype. Diameter of spicule $15.0 \mu \mathrm{m}$; maximum diameter of bundle $=3.5 \mu \mathrm{m}$; maximum diameter of rays $=0.7 \mu \mathrm{m}$.

Remarks. $M$. fasciculata is distinguished from $M$. aciformis by having rays constructed from bundle-like elements and with a free part. $M$. aciformis lacks bundle-like structures and has a greater number of rays.

Monniotia aciformis sp. nov.

(Pl. 4, figs 5-7)

1993 Tunicata spicules Wei: pl. 2, fig. 13.

Derivation of name. From Latin acus, (= needle), and forma $(=$ form $)$ referring to the shape of the rays.

Diagnosis. Species of Monniotia having innumerable needle-like unequal rays without any free part. Only some of the longest rays extend to the centre of the sphere.

Holotype. Pl. 4, fig. 5 (NF514/Neg. 10).

Type and locality. Late Pleistocene (Zone NN21), Red Sea (DSDP Leg 23, Site 229A, Core 2, Section 5, depth $40-45 \mathrm{~cm}$ ).

Dimensions of holotype. Diameter of spicule $=10.5 \mu \mathrm{m}$.

Remarks. $M$. aciformis is distinguished from $M$. fasciculata by having a greater number of rays and the absence of bundle-like elements. In addition, the rays in $M$. aciformis have no free part.

Occurrence. $M$. aciformis occurs in Pleistocene sediments of the Red Sea.

\section{ACKNOWLEDGEMENTS}

$\mathrm{Mr}$ D. Harrison (Simon Petroleum Technology), Dr J. Young, Dr Wuchung Wei and an anonymous reviewer are thanked for their help, advice and constructive review on a draft of the manuscript. Thanks are also due to $\mathrm{Mr} \mathrm{A}$. Davies (University College North Wales, Bangor) for assistance during SEM examination. Samples from DSDP Site 292 A were aupplied by the Ocean Drilling Program.

\section{Received May 1993 \\ Accepted August 1995}

\section{REFERENCES}

Barnes, R. D. 1980. Invertebrate Zoology. Saunders Collcge, Philadelphia.

Beall, A. \& Fischer, A. G. 1963. Sedimentology. In Ewing, M., Lamar Worzel, J. et al. Initial Reports of the Deep Sea Drilling

Fig. 1. Micrascidites vulgaris sp. nov. $\times 12000$. Fig. 2. Micrascidites pauciradiatus sp. nov. $\times 11000$. Fig. 3. Rigaudia cf. praecsia sp. nov. $\times 12000$. Fig. 4. Bonetia acuta sp. nov. $\times 15000$. Fig. 5. Bonetia brevis sp. nov. From middle miocene of southern Turkey $\times 14000$. Fig. 6. Bonetia? sp. sp. nov. $\times 6800$. Fig. 7. Bonetia quasitruncata sp. nov. $\times 3500$. 

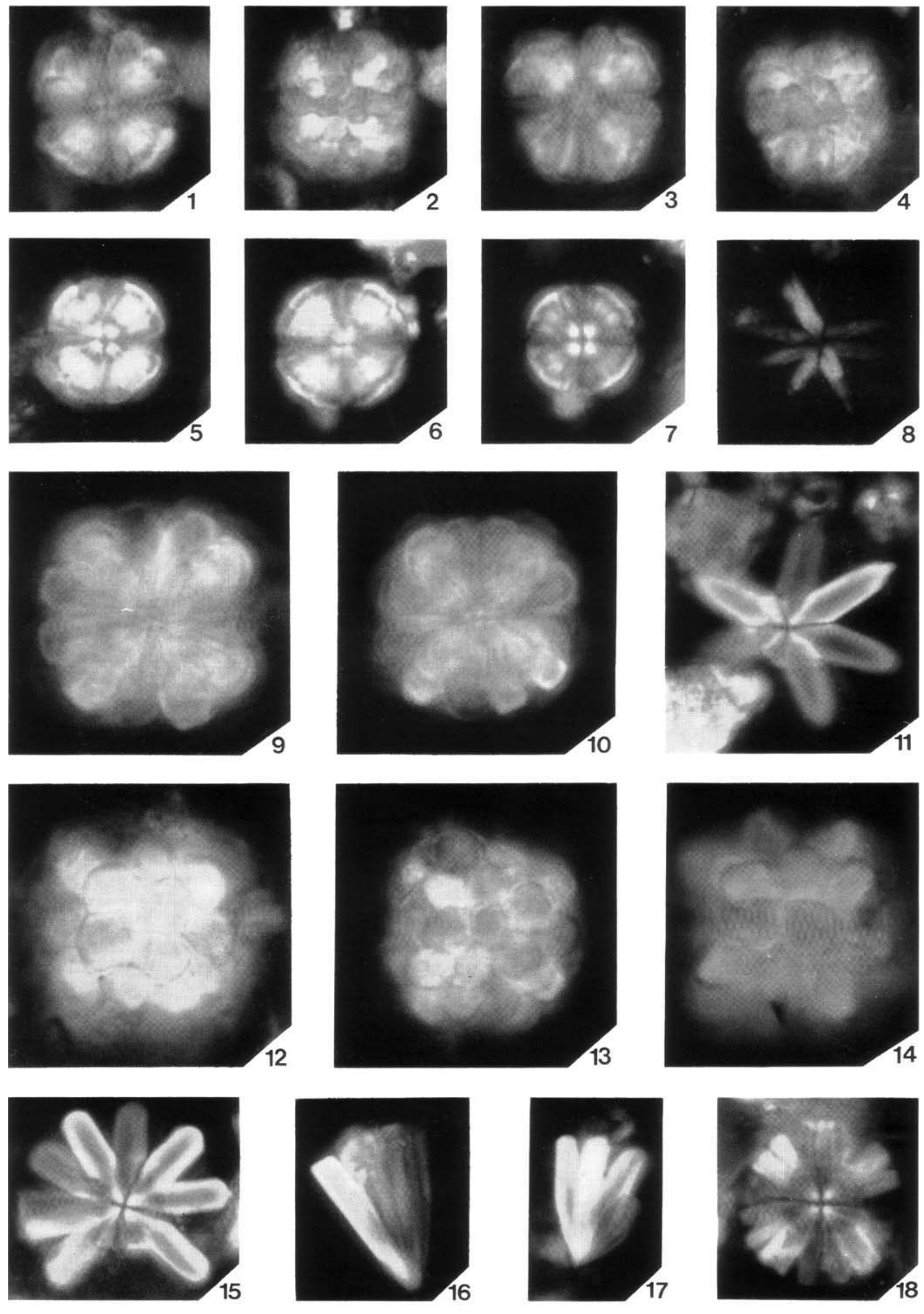
Program, 1: 521-593, US Government Printing Office Washington.

Bergen, J. A. 1985. Nannofossil Biostratigraphy at Site 585, Eas Mariana Basin. In Moberly, R., Schlange R, S. O. et al. Initial Reports of the Deep Sea Drilling Project, 89: 285-296. US Government Printing Office, Washington.

Berrill, N. J. 1950. The tunicata, with an account of British species. Proceedings of the Royal Society of London, 133: 1-354.

Blainville, H. M. D. de. 1825. Manuel de Malacologie et de Conchologie. Libraire F. G. Lavrault Libraire, Paris.

Boekschoten, 1981. Autopalaeontology of Ascidians. Neues Jahrbuch Paläontologie Abhandlungen, 2: 76-83.

Bonet, F. \& Benveniste-Velasquez, N. 1971. Espiculas de ascidies fosiles y actulaes. Revista del Instituto Mexicano del Petroleo, 3: 8-35.

Bouche, F. M. 1962. Nannofossiles calcaires du Lutétien du Bassin de Paris. Revue de Micropaléontologie, 5: 75-103.

Bralower, T. J., Bown, P. R. \& Siesser, W. G. 1991. Significance of Upper Triassic nannofossils from the Southern Hemisphere (ODP Leg 122, Wombat Plateau, NW Austratia. Marine Micropaleontology, 17: 119-154.

Brookfield, M. E. 1988. Where are all the fossil sea squirts? Micropaleontology, 34: 277-283.

Buge, E. \& Monniot, F. 1972. Nouveaux spicules d'Ascidies de l'Yprésian du bassin de Paris et du Toarcien des Deux-Seures. Geobios, 5: 83-90.

Bukry, D. 1975. Coccolith and silicoflagellate stratigraphy, North western Pacific Ocean Deep Sea Drilling Project Leg 32. In Larson, R. L., Moberly, R. et al. Initial Reports of the Deep Sea Drilling Project, 32: 677-701, US Government Printing Office, Washington.

Chauvel, J. 1952. Microfossiles du Pliocene se Saint-Jean-la-Poterie (Morbihan). 76 Congres de Société de Savantes, Rennes, 195I, $159-162$.

Cita. M. B. 1973. Inventory of biostratigraphical findings and problems. In Ryan, W. B. F., Hsu, K. J. et al. Initial Reports of the Deep Sea Drilling Project, 13: 1045-1065, US Government Printing Office, Washington.

Cita, M. B. \& Gartner, S. 1971. Deep Sea Upper Cretaceous from the Western North Atlantic. In Farinacci, A. (Ed.), Proceedings of the II Planktonic Conference Roma 1970. Edizioni Tecnoscienza, 1: 287-319.

Deflandre, (3. \& Deflandre-Rigaud, M. 1956. Micrascidites manip. nov., sclerites de Didemnides (Ascidies, Tuniciers) fossiles due Lutétian du Bassin Parisien et du Balcombien d'Australia. Compte Rendue Sommaire de la Société Géologique de France, 4: 47-48.

Deflandre-Rigaud, M. 1949. Quelques observations sur les spicules d'Eponges calcaires fossiles. Microscopie, 1: 151-161.

Deflandre-Rigaud, M. 1956. Les sclerites d'Alcyonaires fossiles. Elements d'une especie nouvelle: $N$. stellatus. Cahiers de Micropalécuntologie, 1: 1-7.

Deflandre-Rigaud, M. 1968. Remarques sur le genre Neanthozoites Defl.-Rig. a propos d'une espece nouvelle: $N$. stellatatua Cahiers de Micropaléontologie, 1: 1-7.

Durand, S. 1948. Presence de spicules d'Ascidies dans le Redonien d'Apigne (Ille-et-Vilaine). Compte Rendue de l'Académié des Sciences de Paris, 227: 683-684.

Durand, S. 1952. Étude préliminaire du Bassin tertiaire de Gambon. 76 Comptes Rendus du Congress des Sociétés Savantes de Paris a Departement Section des sciences 195I: 149-158.

Durand, S. 1955. Donnees nouvelles pour l'etude du tertiare dela region de Rennes. Bulletin de la Société de géologie et minéralogie de Bretagne, 1: 36-53.
Durand, S. \& Pelhate, A. 1961. A propos des microfossiles des sediments dandriens du Massif armoricain. Compte Randue de somm. Société de Géologie France, 6: 167-168.

Edwards, A. R. 1973. Calcareous nannofossils from the southwest Pacific Deep Sea Drilling Project, Leg 21. In Kennett, S. P., Houtz, R. E. et al. Initial Reports of the Deep Sea Drilling Project, 21: 641-691. US Government printing Press, Washington.

Elredge, L. G. 1966. A taxonomic review of Indo-Pacific didemnid ascidians and description of twenty three Central Pacific species. Micronesic, 2: 161-216.

Hardman, W. A. 1886. Report on the tunicata collected during the voyage of the H.M.S. Challenger during the years 1873-1876. Part II. Ascidia compositae. Report of the Scientific Results of the Voyage of the H.M.S. Challenger, Zoology, 14: 1-43.

Heckel, H. 1973. Late Oligocene to Recent nannoplankton from the Capricorn Basin (Great Barrier Reef Area). Geological Survey of Queensland Publication, 359: 1-24.

Houghton, S. D. \& Jenkins, D. G. 1988. Subtropical microfossil indicators from the Pliocene Celtic Sea. Marine Geology, 79: 119-126.

Jafar, S. A. 1983. Significance of late Triassic calcareous nannoplankton from Austria and southern Germany. Neues Jahrbuch Geologie und Paläeontologie Abhandlungen, 166: 218-259.

Kok, C. P. 1985. An early Cretaceous nannofossil from the central North Sea. International Nannoplankton Newsletter, 7: 38.

Kott, P. 1969. Antarctic Ascidiacea, Volume 13, Antarctic Research Series. American Geophysical Union, National Academy of Sciences Publication No. 1725.

Lafargue, P. F. \& Kniprath, F. 1978. Formation des spicules de Didemnidae. Marine Biology, 45: 175-184.

Lahaille, F. 1886. Sur la classification des tuniciers. Comptes Rendu de l'Academie des Sciences de Paris, 102: 1573-1575.

Lamarck, J. B. 1816. les tuniciers (Tunicata). Histoire naturelle des animaux sans vertébrés. Libraire Verdière, Paris, 3: 80-130.

Land, L. S. 1970. Phreatic versus meteoric diagensis of limestones. Evidence from a fossil water table. Sedimentology, 14: 175-185.

Lazaud, L. 1966. Les nannofossiles calcaires de la formation de Varengeville (Cuisien, cap D'Ailly, Seine-Maritime). Bulletin de la Société Géologie de Normandie, 56: 41-44.

Loewig, C. \& Koelliker, R. E. von 1846. Observations sur l'existence d'une substance ternaire, identique avec la cellulose dans une classe d'animaux sans vertébrés, les Tuniciers. Comptes Rendue de l'Académie des Sciences de Paris, 22: 38-40.

Matthews, R. K. 1966. Genesis of recent lime mud in Southern British Honduras. Journal of Sedimentary Petrology, 36: 428-454.

Michelsen, W. 1919. Zur Kenntnis der Didemniden. Abhandlungen Naturwissenshasten. Herausgegeben vom Naturwissenschaftlichen Verein. Hamburg, 21: 1-44.

Milne Edwards, H. 1841. Observations sur les acidies composées des côtés de la Manche. Memoires de l'Académie Royale Sciences de la Institute de France, 18: 217-326.

Monniot, F. 1970. Cystodytes incrassatus nov. sp. Ascidie fossile du Pliocene, Breton. Compte Rendu de l'Académie des sciences de Paris, ser. D., 271: 2280-2282.

Monniott, F. \& Buge, E. 1971. Les spicules dascidies fossiles et actuelles. Annales de Paléontologie, 57: 93-105.

Perch-Nielsen, K. 1988. New Lower Cretaceous nannofossil species from England. International Nannoplankton Newsletter, 10: $30-36$.

Pérès, J. M. 1947. Note sur le genre Trididemnum dans le région de Dinard, accompagne de remarques sur les organes lateraux des Didemnidae. Bulletin de l'Institute de Océanographie de Monaco, 914: $1-15$.

\section{Explanation of Plate 4}

All figs $\times 2400$. Figs 1-4. Monniotia fasciculata. Figs 5-7. Monniotia aciformis. Holotype (Fig. 5). Fig. 8. Micrascidites sp. (Upper Oligocene India). Figs 9-10. Bonetia quasitruncata. Fig. 11. Micrascidites sp. Figs 12-13. Bonetia brevis. Fig. 14. Bonetia acuta. Figs 15-17. Rigaudia praecisa. Fig. 18. Rigaudia cf. multiradiata. 
Varol \& Houghton
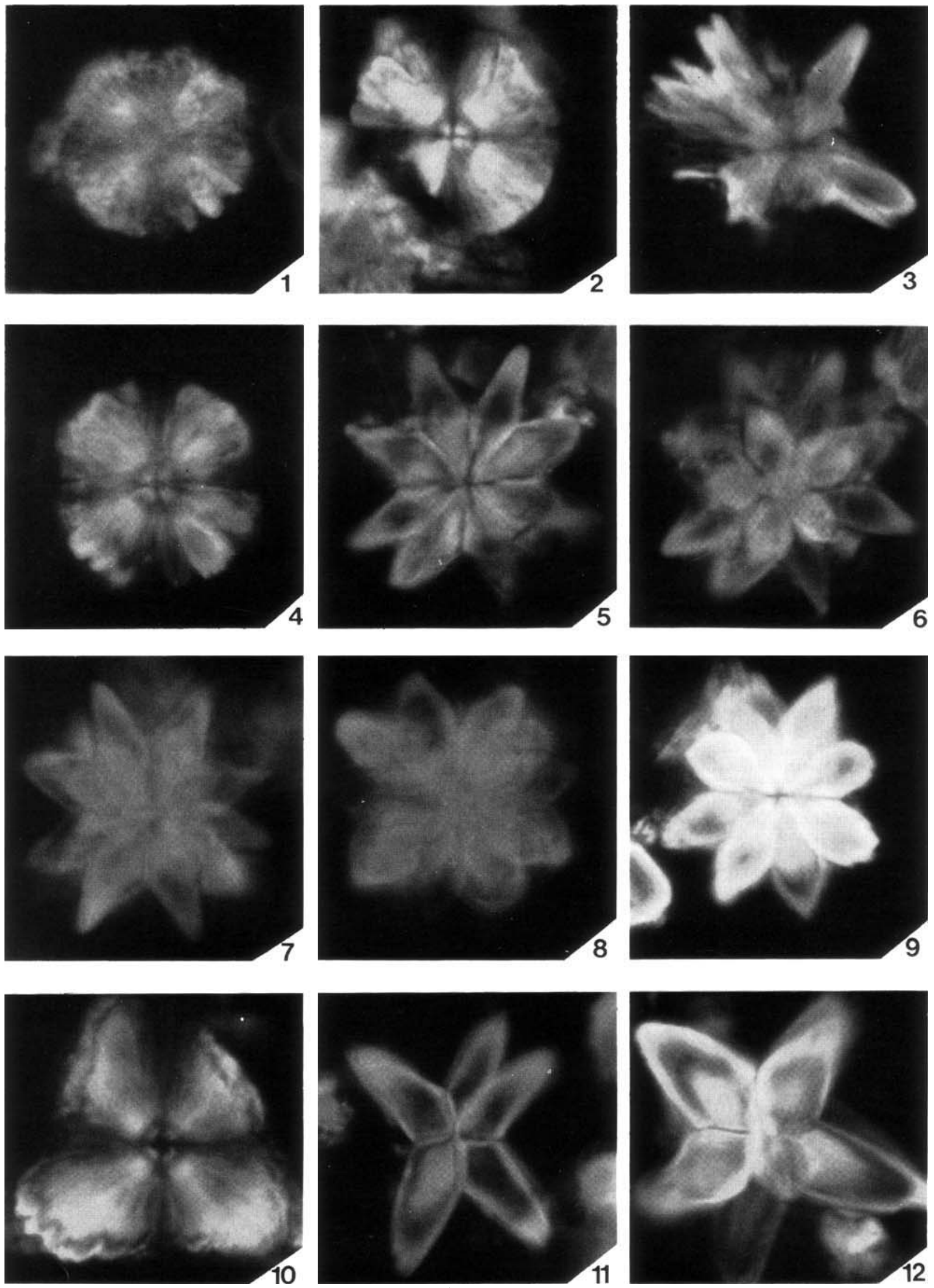
Perrier, E. 1898. Note sur le classification des Tunciers. Compte Rendue de Academie de Sciences de Paris, 126: 1758-1762.

Plough, H. H. 1978. Sea squirts of the Atlantic continental shelf from maine to Texas. John Hopkins University Press, Baltimore.

Prenant. M. 1925. Contributions à l'étude cytologique de calcaire. II. Sur les condition de formation des spicules chez les Didennidae. Bulletin de Biologie de France et Belgique, 59: 403-4.53.

Purdy, E. G. 1963. Recent calcium carbonate facies of the Great Bahama Bank. 1. Petrography and reaction groups. Journal of Geology, 71: 334-355.

Rae, B. B. 1967. The food of cod in the North sea and on the west coast of Scotland. Marine Research, 1: 1-68.

Stiegletz, R. D. 1972. Scanning electron microscopy of the fine-grained fraction of Recent carbonate sediments from Bimini. Bahamas. Journal of Sedimentology and Petrology, 42: 211-226.

Van Name, W. G. 1945. The North and South American Ascidians. American Museum of Natural History Bulletin, N.Y., 84: 1-476.

Van Name, W. G. 1952. Tunicata. The "Manihiae" Expedition to the Gulf of A gaba (VIII). Bulletin of the British Museum (Natural History), Zoology Series, 1: 215-220.

Van Niel, B. E. 1994. Scanning electron micrographs of the genus
Kokia (incertae sedis). Journal of Nannoplankton Research, 16: 75-77.

Varol, O. 1983. Late Cretaceous-Palaeocene calcareous nannofossils from the Kokaksu Section (Zonguldak, Northern Turkey). Neus Jahrbuch Paläontologie Abhandlungen, 166: 431-460.

Varol, O. 1985. Miocene calcareous nannofossils from the Mut basin, southern Turkey. Journal of Micropalaeontology, 4: $127-139$.

Varol, O. \& Girgis, M. H. 1994. New taxa and taxonomy of some Jurassic to Cretaceous calcareous nannofossils. Cretaceous Research, Neues Jahrbuch Palaontologie Abhandlungen, 192: 221-253.

Wei, W. 1993. Abundance patterns of Tunicate spicules at the Great Barrier Reef-Queensland Plateau Transect sites: Implications for downslope transport and Early Pleistocene initiation of the Central Great Barrier Reef. In McKenzie, J. A., Davies, P. J., Palmer-Julson, A. et al. Proceedings of the Ocean Drilling Program, Scientific Results, College Station, TX (Ocean Drilling Program) 133: 447-453.

Woodland, W. N. F. 1907. Studies in spicule formation. VI. The scleroblastic development of the spicules in some Mollusca and in one genus of colonial ascidians (Leptoclinum). Quarterly Journat of the Microscopic Society, 51: 45-53.

All figs $\times 2400$. Figs 1-4. Rigaudia multiradiata sp. nov. Figs 5-9. Micrascidites vulgaris sp. nov. Fig. 10. species and genus indeterminate sp. nov. Figs 11-12. Micrascidites pauciradiatus sp. nov. Holotype (Fig. 11). 